\title{
6 Patrimonialism: The New Order and Beyond
}

\author{
JAMIE MACKIE
}

Harold Crouch's 1979 article on 'Patrimonialism and Military Rule in Indonesia' was in my view one of the most illuminating contributions to our understanding of the New Order political system published anywhere during its thirty-two year history (Crouch 1979). By drawing attention to the importance of patronage and the various forms of patron-client relationship which became so prominent under Soeharto's rule, it provided a more satisfactory macro-level explanation of some of its most puzzling features than has ever been advanced by any other political scientist. Various forms of patronage are to be found in most developing countries, of course, perhaps all, and are easily observable in nearby Malaysia, Thailand and the Philippines (especially in the Marcos years), although much less so in Singapore, for its own unique reasons. ${ }^{1}$ But none of them is usually characterised as a patrimonial political system to the degree that Indonesia was under Soeharto. Why that is so is no great puzzle, but worth considering later for the light it throws on the singular characteristics of the Indonesian political system which have led us to describe it in terms of its patrimonialist features.

His article still stands as a persuasive and insightful analysis of the modalities of Soeharto's regime when he and it were both approaching the height of their power. Although I disagree slightly with some parts of his argument, Crouch certainly made us much more aware than we had been previously of patronage as a crucial feature of Soeharto's political system that became more and more deeply entrenched under his rule (almost intentionally so, I will suggest), becoming especially prominent after 1980 as his political authority became unchallengeable and the financial resources under his direct control increased enormously. Patronage has continued to be an important aspect of the "money

\footnotetext{
1 Singapore under Lee Kuan Yew and his successors could not in the least be described as a patrimonialist regime, despite its strongly authoritarian aspects. Patronage relationships of the Soeharto type play little part, if any, in maintaining the enduring dominance of his party, the PAP (or his authority within it), or Lee's influence over the business world. The preponderance of public-sector corporations and foreign business firms over the feeble private business sector, coupled with Lee's extraordinary success in refusing to tolerate corruption among government officials (a legacy of his early Socialist inclinations and singular financial puritanism) has made Singapore's experience of business-government relations quite unique.
} 
politics' of the post-Soeharto system of governance also, even under democracy and reform (demokrasi dan reformasi), but in a very different political context, as if it has become almost a pathological feature of the Indonesian political system - with damaging socio-political effects which I suspect will not easily be remedied. But patrimonialism implies something more than mere patronage, as we shall see, and while several aspects of the New Order patrimonialist system still persist, it would be going too far to categorise the post-1998 political order as such.

President Soeharto's ability to utilise patronage extensively to ensure the loyalty of his subordinates and leading members of the national elite, coupled with the formidable coercive powers at his disposal as head of the Armed Forces (in particular its intelligence apparatus) and the huge advantage of vastly greater financial resources available to him than his predecessor, President Sukarno, could ever dream of, plus the immense concentration of many strands of political, military and financial power he was able to bring together in his own hands at the apex of the political system, all had the cumulative effect that he wielded virtually unchallengeable control by the early 1980s which lasted until early 1998. It was partly because the system of government he created had some intriguing similarities with the patrimonial power of traditional rulers in the pre-colonial past that the term 'patrimonialism' initially seemed appropriate for his regime, although there were clearly some important differences. ${ }^{2}$ But the key aspects of New Order patrimonialism had much deeper roots than just that. If we assume that the word refers primarily to the patronage aspect of Soeharto's regime, along with various other features mentioned above, it provides a better characterisation of the regime than any of the other catch-phrases commonly used to describe it, such as militarist, dictatorial, neo-colonialist, bureaucratic authoritarian and so on (see Anderson and Kahin 1982).

The word patrimonialism had not been widely used with reference to Indonesia before 1979, except rather briefly in Benedict Anderson's famous 1972 article on 'The Idea of Power in Javanese Culture', which may have drawn Crouch's attention to the concept (Anderson 1972). But Crouch's article brought it into far greater prominence. In fact, the term has since proved to be even more apposite to our analyses of the second half of Soeharto's rule, for reasons I discuss below, than it had been prior to the late 1970s when Crouch's ideas on the matter were taking shape. (That post-1979 tendency ran counter to the main thrust of his argument, however, which was that patrimonialist tendencies and a modern socio-political system were essentially incompatible.) The term also

2 Crouch summarised the differences between traditional patrimonial states and modern ones with patrimonial features on pp. 572-23 of 'Patrimonialism', stating that 'the environment in which patrimonial characteristics have persisted has been very different from the one in which they originally appeared. Modernisation has brought new challenges that threaten the capacity of governments to meet demands and maintain stability.' 
has quite direct relevance to the post-Soeharto period, insofar as patronage is still a widespread feature of the political system that has taken shape since 1998, along with the general assumption which still persists that official positions can and will be used for purposes, inter alia, of personal or group benefit. But the patrimonialist aspect of the demokrasi dan reformasi years since 1998 has been submerged beneath the new and very different phenomenon of 'money politics', which is now so prevalent at both the local and the national level, as well as the far more pluralist character of the political system. Yet some vestiges of the mentalite associated with traditional patrimonialism still persist and are unlikely to fade into obscurity for many years.

In reviewing Crouch's argument about patrimonialism and its applicability to Indonesian politics, this chapter takes the view that while he accurately identified the key political dynamics of the New Order system as they were emerging in the late 1970s, he overestimated the degree to which the modern features of the regime would necessarily prove incompatible with its apparently traditional patrimonial underpinnings. As we shall see, the patrimonial character of the regime, deriving largely from Soeharto's ability to bestow patronage in return for loyalty (or, equally important, use the sanction of withholding it where necessary), became an increasingly prominent feature of the system of government he created and personally controlled in virtually all its key aspects. As such, far from leading towards a crisis for his regime, it was one of the factors contributing towards its longevity.

\section{Patronage and patrimonialism}

Patronage and patrimonialism are distinct but closely intertwined concepts which need to be clarified before we go any further. The former is a fairly straight-forward term referring to a particular kind of mutual relationship, usually between a (relatively) wealthy patron and a needy or dependent client. It is not necessary to endow the term with much theoretical baggage, for we can usually recognise a pay-off or a patron-client relationship whenever we encounter one. They were often seen in traditional Southeast Asian societies, while latter-day variants of them are still to be found today both in Indonesia and in other countries nearby.

But the word patrimonialism is a very different matter, for it is a much more abstract notion referring to an entire socio-political system rather than a particular kind of easily recognisable relationship, such as patronage. Patrimonialism, as I will be using the term here, refers essentially to a system that is, first, based very largely on patronage, and second, on the granting of quasi-traditional fiefdoms to favoured subordinates, as well as, third, sustained 
largely by personal loyalties similar to those accorded to traditional rulers, although in more modern garb in recent times. ${ }^{3}$ It is a more mesmerising word than patronage, having its own peculiar potency (due in part to its slightly mysterious, exotic quality, or because it is much harder to define or pin down).

Benedict Anderson had written, in the early years of the New Order period, about the 'marked consonance of the traditional Javanese concept of Power with the political structures and behaviour of the patrimonialist state' (Anderson 1972:36). He said of the pre-colonial Javanese state that it 'admirably fits Max Weber's model of the patrimonialist state', in that the government was 'an extension of the person of the ruler'. Officials held their posts and perquisites at his whim and they were paid in the form of 'benefices ... specified'. He noted the 'highly personalistic character of patrimonial rule [there], in which the corps of officials is regarded as an extension of the person of the ruler ... [and] proximity to the ruler, rather than formal ranking, is the key to power'. The reemergence of the patrimonialist model in Indonesia in the mid-1950s (after the 'ration-legalist bureaucracy bequeathed by the Dutch' began to crumble due to financial problems) was, in Anderson's view, accentuated by the persistence of traditional ideas about government that were highly consonant with it (Anderson 1972:35-36).

Weber had analysed various forms of Herrschaft (authority, domination or, perhaps better, in Roth's term, 'rulership'), such as patriarchy, kingship, the 'routinisation of charisma', feudalism, the city-state and patrimonialism in his massive study of Economy and Society. ${ }^{4}$ He introduced the word patrimonialism in a chapter on 'Gerontocracy, Patriarchy and Patrimonialism' in his section on 'traditional authority', noting that the first two of these are 'the most elementary types of traditional domination' where there is a complete absence of personal, patrimonial staff. Patrimonialism (and 'sultanism', its most extreme form) arise 'when traditional domination develops an administrative and military force that are purely political instruments of the master.' Weber adds 'We shall speak of a patrimonial state when the prince organises his political power over extrapatrimonial areas and political subjects - which is not discretionary and

\footnotetext{
3 Attitudes to authority, deference to superiors and a reluctance to express open opposition face to face even among equals are amongst the various so-called 'Javanese' qualities of mind which came to be widespread under the New Order political system and certainly helped to reinforce it. While they have been displaced to some extent in the demokrasi dan reformasi years (but by no means totally) I suspect that much of the tolerance of official corruption and patronage relationships that still prevails derives largely from that older cluster of values and attitudes associated with patrimonialism.

4 Max Weber, Economy and Society, New York 1968, 3 vols, $231 \mathrm{ff}$; this work first published in German in 1922, not long after Weber's death (and still unfinished) was a huge, wide-ranging survey of diverse types of state, semi-sociological and semi-historical in approach, covering many centuries from the pharaohs to medieval European city-states, Middle Eastern sultanates and others. According to Roth, 1968, pp.194-206, Weber's goal was to try to discover 'how the systems really work', as well as to theorise about their sociopolitical dynamics and the differences between them. It seems that Southeast Asian kingdoms, sultanates and principalities were utterly unknown to him.
} 
not enforced by physical coercion, just like the exercise of his patriarchal power' (Weber 1968:1013). (By the latter he meant a situation where the authority of a patriarch was never challenged.) Originally, patrimonial administration 'was adapted to the satisfaction of the purely personal, primarily private needs of the master'. However, in more complex societies, such as the city-states of medieval Italy, the patrimonial ruler had to draw the privileged strata to his side by reserving key positions in the standing army for them and creating an army of professional soldiers, equipped with supplies and revenues that were provided by the ruler. The army was dependent on the ruler, and vice versa.

In applying Weber's analysis of patrimonialism to the more modern world, we should avoid thinking of it in an essentialist way, as if there is some fundamentally distinctive feature that marks it out from other types of Herrschaft, in the way he had categorised them, and think of it instead as simply a cluster of characteristics that will be found in varying proportions, more so or less, in different polities or at different times. (Soeharto's regime became much more patrimonial in that sense in the latter part of his rule than in the years Crouch was analyzing, it seems to me.) The key features include the personal authority of the ruler (howsoever achieved), the traditionalist accoutrements of such authority, the hierarchical array of subordinate authorities reaching from the apex of the state to the lowest levels, and the patron-client relationships that tie them all together. Another of Weber's key observations, for our purposes, is that patrimonial rulers, like all traditional rulers, must endeavour to maximise their personal leverage over their subordinates in a constant tussle over who has ultimate control.

\section{Indonesian patrimonialism in Crouch's account}

Crouch had earlier made many references to the practice of patronage in both Sukarno's and Soeharto's regime in his 1978 book on The Army and Politics in Indonesia although without using the term patrimonialism or any mention of Weber (Crouch 1978). But he developed their relevance to Indonesia much more explicitly in his World Politics article with a fuller analysis of the patrimonial and neo-patrimonial features of the Indonesian political system under Sukarno as well as Soeharto, citing works by Roth, who had co-edited Weber's major work on the subject, and Eisenstadt, who had applied his ideas to the newly modernising nations. Yet Crouch avoided becoming caught up in the theoretical complexities of Weber's thinking on the subject. His focus was more on the persistence of traditional features of modernising polities and how far their 'modern' features had replaced or modified the traditional elements in the postindependence Indonesian socio-political system, citing Geertz's (1960) and AnnRuth Willner's (1966) writings on that theme. Although Indonesian society had 
experienced great social change, with the Indonesian Communist Party (Partai Komunis Indonesia, PKI) mobilising wide popular support among the masses in the 1960s, the prominence of traditional features of both the New Order and Sukarno's 'Old Order' still seemed 'to hark back to the traditional patrimonial polities of earlier Javanese empires.' (Crouch 1979:573)

However, what Crouch concentrates on in his 1979 article is perhaps the most striking feature of modern Indonesian patrimonialism: the allocation of lucrative fiefdoms from which the President's subordinates could derive their funds for both official and private purposes, under both Sukarno and Soeharto. The expansion of Soeharto's authority, says Crouch, was backed at first by his growing capacity to use coercion against resisting groups, but later the main means was through the distribution of patronage.

He was able to reward loyal supporters and win over potentially dissident officers with appointments to civilian posts that offered prospects of material gain. Control over the machinery of patronage ... was thus the key factor that enabled Suharto to win and maintain the support of the armed forces for his leadership. (Crouch 1979:577)

Under the New Order, in Crouch's words, 'the enforced political isolation of the masses ... was a factor favourable to the emergence of a new patrimonial system ... [and] patrimonial politics again took the form of a struggle for influence within the elite.' (Crouch 1979:576). With the PKI eliminated and the masses effectively excluded from political activity by the de-politicisation processes of the 1970s, patrimonialist politics 'again took the form of a struggle for influence within the elite' which Soeharto also kept within bounds through the distribution of patronage. Hence the new regime 'bore a strong resemblance to the patrimonial model. Political competition among the elite did not involve policies but power ... and the distribution of spoils.' (Crouch 1979:578)

Although facilitated by the elimination of the PKI, this was not an entirely new development, however, for Sukarno too had maintained a patrimonial regime during his Guided Democracy years (1959-65). 'In the patrimonial atmosphere of Guided Democracy, army officers - like most other officials - had used their [official] position to further their private interests'.

Whether or not they had been able to do so in the Sukarno years to the same extent as they did under Soeharto, or as such a central feature of Sukarno's political system, may be debateable. But Crouch is surely right in his view that Sukarno had to rely on the distribution of favours to his followers to maintain a balance between them because he was unable to exert much coercive power against them. Like the sultans in the patrimonial states of the past, Sukarno had managed to 
keep the courtiers jostling among themselves for his favours in order not to become too dependent on any one of them ... But Sukarno's courtiers were backed by modern organizations and he had no way of effecting a reconciliation between the interests and organizations they represented in the nation. (Crouch 1979:574)

That last point is important, for it touches on a key reason Crouch advances for his underlying belief that 'patrimonial ritual and the distribution of fiefdoms proved insufficient to hold together a polity that was sharply divided' under Sukarno. It may have seemed to be patrimonial, he says, but the disintegration of his regime in 1965 revealed that it was not. Yet that observation was surely an oversimplification. The collapse of Sukarno's Nasakom regime after the Gestapu coup attempt of September 1965 had little or nothing to do with its patrimonialist features but was due primarily to the destruction of the political balance that he had previously been able to maintain between the contending (modern) political forces, PKI on one side and the anti-Communists, principally the Army, on the other. And it was not patronage and fiefdoms that he provided to the PKI (or withheld from them) but political protection, which was crucial for it.

Crouch seems to have viewed Soeharto's New Order as basically similar to Sukarno's regime because of its patrimonialist features; hence he concluded that Soeharto's regime would eventually suffer the same fate as Sukarno's, for a similar reason, an inevitable clash between the traditional and the modern. Yet while he leaves us in no doubt about the crucial patrimonial aspects of the New Order, he did not assert bluntly that the New Order was a patrimonialist system. On the contrary, he says quite explicitly in his concluding sentence that while the regime may have appeared to be a patrimonial one and bore a strong resemblance to Weber's patrimonialist model, 'Indonesia's apparently patrimonial structures have been built on non-patrimonial foundations, with the result that patrimonial-type stability is not likely to endure.' (Crouch 1979:587)

In his view, the New Order regime was not exclusively a traditionalist and patrimonial regime, but one that also had many modern features, especially in its reliance on economic growth for legitimacy.

The New Order government's dependence on economic growth seems to require an administrative system based on the bureaucratic values of predictability, regularity, order and rationality - in contrast to patrimonial favouritism and arbitrariness. As a result, basic conflicts over policy and the nature of the regime are becoming increasingly important. (Crouch 1979:579) 
Crouch asserted that after the 1974-75 financial disasters in Pertamina and Bulog, Soeharto's ability to go on relying on patrimonialist formulae seemed to be coming under threat. He referred to 'the emerging conflict within [the army] with ideological overtones involving contrasting perceptions of government', the holders of patrimonialist benefices being pitted against a group of 'reformminded officers' aligned with the economic technocrats pushing for a Weberian 'rational, predictable' legal and administrative structure favourable to the growth of production-oriented capitalism. Although doubtful that these pressures would be strong enough to result in 'the establishment of a Weberian legalrational order in the immediate future', he expected there would be an increase in political conflict within the military elite and a breakdown of Soeharto's essentially patrimonialist system. Hence his conclusion, that 'patrimonial-style stability is not likely to endure' because the government will find itself forced to 'give greater emphasis to straightforward repression and less to the buying-off of dissidents.' (Crouch 1979:586-87). The system could not survive just on the basis of 'patrimonial favouritism and spoils.'

The later course of events in the 1980s did not bear out that prediction, however. During that decade, repression diminished (albeit slightly) rather than intensified. The rift between 'reform-minded officers' and the old-timers who held patrimonial benefices largely disappeared into the sands of time, as virtually all of them became drawn into the system in varying degrees. We heard almost nothing more of any challenge to the regime by them in the later years of the New Order. And the Soeharto regime continued to survive and flourish for roughly twenty years after Crouch wrote his article. It is even arguable that he might have remained in office much longer if the Asia-wide 'financial meltdown' of 1997-98 had not suddenly disrupted the Indonesian economy severely through the abrupt withdrawal of short-term foreign capital (an externally generated shock-wave, not primarily a domestic one), plunging the country into a crisis which shattered his authority terminally. But how far that crisis and his overthrow were attributable to the patrimonialist character of the regime or to other factors in the brittle political structure prevailing in 1997-98 is a contentious question to which I will return shortly. It was no doubt one of the many factors involved in the witches' brew of troubles which came to a head in May 1998 and left Soeharto with no option but to resign. But the assertion Crouch had made in his article that the New Order could not survive on the basis of 'patrimonial favouritism and spoils' alone seems to depend on an assumption that patrimonialism and real modernisation were incompatible, which I regard as a moot point, to say the least.

That view reflects the arguments that were in contention in the 1970s about the political dynamics of traditional as against modernising polities which we need not go into here. Crouch seems to have assumed that because of its highly 
mobilised mass organisations (prior to 1965, at least), modern ideologies and a politically conscious, influential corps of military officers, Indonesia now belonged at the modernising end of that spectrum, where there was no longer any place for a patrimonialist system of government. My own view would be that while we may all have hoped that was the case, hindsight reveals to us that the reality was very different. While there is no doubt that patrimonialism is an unhealthy pathology in a truly modern system of government it is surely an overstatement to call it incompatible with modernisation? Other modernising, or rational-legal regimes have been able to tolerate the persistence of patrimonialist elements to some degree. Soeharto was able to maintain them and rely on them to preserve his regime until the economic crisis reached its peak in early 1998.

\section{The post-1979 entrenchment of the patrimonial system}

The title of Crouch's 1979 article referred to patrimonialism and military rule, not specifically to it as the basis for President Soeharto's personal authority or rulership. In fact he does not say much at all in it about the great personal ascendancy Soeharto was building up within the New Order power structure even before 1979, partly, I suspect, because that ascendancy was not nearly as striking as it became in the decades following; in fact, it did not become at all securely established until after the troubled years 1975-78. In later years, when the senior officers military came to be more fully under Soeharto's control and his personal authority was unchallenged, the focus on him would no doubt have been much sharper.

In fact it is worth recalling that Crouch's article appeared just when the New Order regime was changing gears, as we might say, from its initially rather tentative search for a political format (Feith's apt phrase of 1968) to one which became far more set in its ways, more patrimonialist, powerful, personalised and later even 'sultanist'. After about 1980-81 any overt challenge to the authority of the president was a very risky course to embark on, as several generals discovered to their cost. ${ }^{5}$ It is often forgotten now, when the New Order period is viewed in retrospect as one long continuum of Soeharto's dominance, that in fact his position had seemed far from secure in 1975-76 when there was a great deal of speculation about his possible political demise.

The changes that occurred after about 1979-80 were far-reaching. It was not just that Soeharto stared down the group of senior generals associated with the

5 The Petisi 50 group of generals who issued a strongly critical statement about the President's policies in 1980 were very abruptly repudiated and sidelined; see David Jenkins, 1982. 
Petisi 50 group and had no further trouble from them, as well as imposing tight discipline over university students through the tough regulations imposed by Daoed Yusuf, his hard-line Minister for Education; it was also that the second oil boom of 1979-80 and the healthy state of the economy in the following years provided him with vastly greater financial resources than ever before which enabled him to allot lucrative fiefdoms to subordinates who were loyal to him, while punishing any whom he suspected of disloyalty by keeping them away from any of the government's now ample honey-pots. Moreover, he curbed any tendency for rival clusters of power to develop, far more effectively than he had been able to do earlier. His control over the military became much tighter as the 1945 Generation of senior officers gave way to the Magelang-trained younger generation with no experience of the revolution, hence greatly in awe of him. The Consultative Assembly (Majelis Permusyawaratan Rakyat, MPR) declared him 'Bapak Pembangunan' in 1983 and the FAO honoured him personally in 1984 for Indonesia's achievement of rice self-sufficiency. His performance legitimacy, which had been under a cloud during the late 1970s when the Green Revolution seemed likely to be derailed in its prime by the 1975-76 wereng (brown hopper) plague, was beyond question in the early 1980s, despite momentary hiccups due to oil price falls in 1981-82 and 1986, which were soon cured by the staunch economic policies of his technocratic ministers.

The most striking feature of the patrimonialist system of governance that developed in the 1980s, however, was not just the use of patronage to maintain the loyalty of the president's immediate subordinates but the way he ensured the dependent status of all officials and civil servants by keeping their official salaries and allowances too low to subsist on without resorting to 'unconventional finances' or various forms of corrupt practice. The salary levels of civil servants (pegawai negeri) were raised by only trivial amounts. That meant they were all dependent on the connivance and approval of their superiors right up the line to the president himself. Yet it was no longer the case that Indonesia was too poor a country to be able to spare the funds needed to pay more adequate salaries to civil servants. Because they were so poorly paid, they were in effect being kept in a condition of virtually complete dependence on the benefices handed out by the government as additional rewards for their obedience and loyalty. While it had perhaps been understandable that Indonesia's governments had earlier lacked the revenues needed to pay their civil servants and military personnel adequate salaries; that was no longer the case by the late 1980s when the funds available were vastly greater. So their high degree of dependence on the largesse made available from on high was simply maintained. I cannot help suspecting that this was deliberate policy on Soeharto's part, for it must have enhanced his control over the entire state apparatus immensely. 
The growing political stature of Soeharto in the 1980s (greatly enhanced by the fact that the economy began to achieve steady growth as the Green Revolution took off and manufacturing industry at last began to develop strongly) may help to explain the resilience of his regime beyond the crisis point which Crouch earlier seemed to expect. In the 1980s, as the patrimonialist aspects of the New Order political system became more and more apparent with the emergence of big conglomerate corporations headed almost entirely by 'crony capitalists' (nearly all Sino-Indonesians) with good connections to the palace, so too did the president's personal predominance within it. As already mentioned, he now had immense financial resources under his control from both the regular budgetary sources (rapidly increasing oil and tax revenues, due in part to a major revamping of the fiscal system in 1983) as well as from what were initially called 'irregular revenues' or later 'off-budget' funds derived mainly from state corporations and other government agencies, not to mention straight-forward bribes paid by private businessmen in return for licenses, concessions and privileges. Control over both economic resources and political power came to be highly concentrated at the apex of the political system, to a degree that had previously been unknown in Indonesia, even under the strongest Dutch governors. So the fiefdoms which Soeharto could allocate to his most loyal subordinates, both civil and military, were now more lucrative and extensive than ever. Anyone who hoped for access to such riches had to be sure to keep on the right side of the president and his state secretary, who kept a close eye on the distribution of all major contracts and benefices. The few who dared to criticise the government in public were utterly excluded from the gravy train. ${ }^{6}$

Even the 'crony' businessmen who had begun to amass huge conglomerates through their contacts with the palace in the 1970s and 1980s were made well aware that it did not pay to try to become too independent of the president or his family. A few tried to do so to a modest extent; but William Suryajaya, who was second only to Liem Sioe Liong/Sudono Salim in the 1980s and tried to keep some distance from the palace after having his fingers burnt in 1974 for being too close to Soeharto's wife, Ibu Tien, was punished very blatantly in 1992 as the price to be paid for such presumption. ${ }^{7}$ The most spectacularly wealthy conglomerates that emerged in the 1990s, on the other hand, were all very closely connected with him or his family. There were simply no alternative sources of political protection or patronage of comparable magnitude to Soeharto, unlike in the Sukarno era, when there was still a degree of pluralism in the system.

\footnotetext{
6 Retribution against dissident generals in the later New Order period took the form, according to General Sukendro, that 'all your lifelines should be cut'. Ali Sadikin said that 'they have cut us off from everything'bank credits from state banks, the right to tender for state contracts, exit permits to travel abroad, even the opportunity to write for newspapers. Jenkins, 1982, p.187.

7 On the emergence of the conglomerates in the 1980s, see Robison, 1986, pp.131-75; Mackie, 1990, pp.7195; Schwarz, 1986, pp.98-132.
} 
Moreover, the patrimonialist character of the entire socio-political system extended down through its lower levels, with governors, district heads (bupati) and subdistrict heads (camat) - and even mere village heads-exercising the same sort of powers of control and patronage in their subordinate offices. No other local official or even a wealthy local businessman could afford to get badly off-side with the president's men. Power flowed down from the top during the last twenty years of Soeharto's rule not up from below (as it had done to some extent amidst all the tumult of 1966-67). The prime reason for that was his ability to keep all his officials, potential rivals and alternative power centres in a position of utter dependency.

Even the threat of regional dissidence which had plagued Indonesia under Sukarno was curbed by maintaining a tight rein over regional finances so that local officials were heavily dependent on the revenues they received from Jakarta, hence on the president's goodwill, as in the classic patrimonialist model. The 1974 law on Decentralisation and Local Autonomy enacted by Soeharto would be more accurately described as a law to centralise control over the provinces and to minimise local autonomy, thereby keeping them in a state of almost complete dependence over the next quarter-century.

Adam Schwarz has mentioned another key aspect of Soeharto's 'patrimonialist style of rule' as it related to tensions between the Chinese capitalists and their pribumi rivals:

No matter how large and powerful the ethnic Chinese businessmen become, they represent no political threat to Suharto because they come from a relatively small minority. But economically powerful pribumi businessmen, freed from reliance on government largesse, would be a different story... [and] could well outgrow a need for Suharto's favour and become a potent political faction. Whether Suharto views his actions in these terms is hard to say, but the top pribumi businessmen certainly see it this way. (Schwarz 1986:127)

A brief comparison of the Indonesian political system with those of Thailand, Malaysia and the Philippines over recent decades will serve to highlight one of the main reasons why the Soeharto regime can appropriately be characterised as patrimonialist whereas the latter three cannot. Since the 1970s, no leader in any of those three countries has held anything like the unassailable and continuing power that Soeharto did. That durability enhanced his power as the sole source of the most lucrative patronage available to any of them enormously. While the others all utilised patronage to the extent they could get away with it, they had nothing like the long-term dominance over the country that Soeharto achieved 
which made him the supreme patron and source of both offices and lucrative fiefdoms, with no rivals or threatening subordinates. Mahathir came closest to matching him in longevity (along with Marcos, discussed below) but he had serious rivals with followings in the United Malays National Organisation (Pertubuhan Kebangsaan Melayu Bersatu, UMNO) and some patronage capacity as ministers - Musa Hitam, Razaleigh and Anwar Ibrahim - whom he could never disregard entirely until after Anwar was shafted in 1999. And both the parliamentary structure, the judiciary and the bureaucracy imposed constraints on his naked use of patronage of a kind that Soeharto never had to bother about. In Thailand, prime ministers (and the parties behind them) came and went so frequently that none had sufficient opportunity to build up the vast networks of dependents among the wealthy Sino-Thai business groups through patronage that Soeharto created via the crony conglomerates. In that respect there was far more pluralism in both the Malaysian and Thai systems than in Indonesia, financial as well as political. The Philippines was a very different story, mainly because it is the one country in Southeast Asia with a substantial propertied class of about 200 wealthy landowning families who have exerted great political influence in Manila ever since independence, as well as immense economic clout in their regions, to a degree that is not replicated in any nearby nation. Marcos could not simply defy or override those interests even during the martial law years between 1972 and his overthrow in 1986 (indirectly caused by the murder of Aquino in 1973, plus mass opposition in Manila) but had to manipulate and accommodate them. Whether or not his regime was more venal, dictatorial or patronage-based than Soeharto's, an arguable question, it could certainly not be described as similarly patrimonialist.

A striking feature of the socio-political and economic structures that have developed since World War II in Thailand, Malaysia and Indonesia (but not the Philippines) is that there is a substantial disjunction between political and economic power in all three of them - as also in Singapore along very different lines. That is due in large part to the economic dominance of the local ethnic Chinese business class in each, coupled with its lack of anything like comparable political influence (except to some degree in Thailand since the late 1980s, where there have been more Sino-Thai prime ministers than ethnic Thai, something that would be inconceivable in Indonesia). That is a situation conducive to patrimonialist or 'sultanist' or patriarchal rule, as in so many pre-modern societies, but against the grain of most modern capitalist countries. It has been avoided in Thailand and Malaysia for rather special local reasons grounded in the historical position of the Chinese minorities there and the pluralist features mentioned above. But patronage is a more prominent feature of the political and economic landscape in Indonesia, widely accepted as a tolerable means of helping to create or support the small emerging class of pribumi businessmen. While that is also true of the other two, it is less marked and less politicised there. 
I suspect that patronage will remain a continuing feature in all three countries, Indonesia especially, until an indigenous capitalist class emerges which starts to see virtue in the idea of level playing-fields and avoidance of special privileges on the basis of patron-client relationships. That will probably not be soon.

Did the patrimonialist character of Soeharto's New Order contribute to the longevity of his rule - or was it, on the contrary, responsible ultimately for the collapse of his regime in 1998? Or both? The answers to these questions must surely be that it was certainly one among a number of factors that contributed to its longevity and also one among those that brought about its final collapse. How great a part, or small, it played on either of these issues could be argued at great length, but I will try to give two brief answers.

As a factor that accounted for its longevity, I would say that it undoubtedly enabled him to retain the loyalty of his subordinates through the use of carrots rather than sticks. And he certainly had a lot of carrots at his disposal during the latter part of his long reign. The lack of any effective opposition to him from within the elite prior to the 1998 crisis must be attributed largely to that. On the other hand, there were other factors that contributed to the longevity of his rule. His 'performance legitimacy' was surely one of the most important, both in his early years when he quickly pulled Indonesia out of the economic and political chaos of the late Sukarno era and steered it towards recovery and ultimate prosperity, as well as in the boom years of the early 1990s which brought unprecedented wealth to large numbers of Indonesians. The fact that he was able to deliver the goods in bad times as well as good, even amidst falling oil prices and bad rice harvests, won him grudging acceptance even among his enemies. Another factor was the persistent hope that the improving political and social conditions that he had brought about and the gradual emergence of a semi-autonomous urban middle class would be followed sooner or later by progress towards a more democratic system of government. This seemed to be borne out by the three brief years of 'openness' (keterbukaan) between 1991-94 - until they were abruptly ended by the banning of Tempo and Editor on absurdly trivial grounds. There was to be no return to that more liberal phase of government until after Soeharto had fallen. And there were growing expectations by the 1990s that his next term in office would turn out to be his last; so no one wanted (or dared) to take the risk of trying openly to dislodge him.

Can the collapse of his regime in 1998 be attributed in a way to its patrimonialist character? Only as a very indirect background factor, I think, insofar as it helps to account for the rigidity of the regime in its final months and for the public dissatisfaction that swelled suddenly and unexpectedly into a tidal wave of 
rejection of Soeharto's iron grip on the presidency in May 1998. Any explanation of how the end came must take account of a number of other elements in the equation that had an effect, some very short-term in their significance, others more deep-seated and persistent. The most important factor, of course, was the catastrophic collapse of the economy after the mid-1997 'financial meltdown' (krismon) which in itself could perhaps have been handled successfully had it not been for the obvious favouritism shown by Soeharto towards his children and their economic interests over the following months. But that was the sin of nepotism, not patrimonialism. It certainly magnified the collapse of public confidence in the competence of his government itself and in the value of the rupiah which fell precipitously, plunging the country into ever deeper economic turmoil. And the fact that the financial crisis occurred just before the March 1998 MPR session to elect or re-elect the president created an exceptionally volatile political climate. But the train of events which followed the shooting of four students at Trisakti University on 12 May and the mass rioting in Jakarta next day when his legitimacy and authority crumbled terminally had little to do with the patrimonialist character of the regime as a direct cause. If anything, the reverse; it was the fact that Soeharto could no longer exert anything like his former sway even over his closest ministers - and their refusal to join the new cabinet he was trying to cobble together in his final days - that made him realise the game was up. ${ }^{8}$

\section{Conclusion}

By characterising the New Order as patrimonialist, Crouch provided a more convincing explanation of its basic dynamics than any previous analyst had done. Modernisation theory, which had exercised a big influence on studies of the developing countries in the early 1960s - in particular on Herb Feith's writings on Indonesia as that time - lost much of its earlier appeal during the Vietnam war decade, especially in the United States. ${ }^{9}$ So there was a theoretical vacuum waiting to be filled. Mortimer had earlier made a strong case for 'bringing class back in' to our explanations of the socio-political dynamics of Indonesian politics in the mid-1960s, but neither his approach nor the dependency theory and neo-colonialist interpretations that became fashionable after the sharp increase in transnational capital inflows of the early 1970s provided a convincing basis for new interpretations of the power structures underpinning Soeharto's regime along those lines (Mortimer 1973:54-68; Mortimer 1982).

8 On the fall of Soeharto in May 1998, good accounts are given in O'Rourke, 2002; and Aspinall, 2005.

9 Herb Feith revealed the early stages of his disillusionment with 'modernisation theory' in his famous reply to Harry Benda's review of his book in the Journal of Asian Studies, 1965, later in an unpublished 1969 article on 'The Study of Indonesian Politics: A Survey and an Apologia', both included in Anderson and Kahin eds, 1982, pp.41-53. 
Benedict Anderson turned that approach on its head by 'bringing the state back in' a few years later, with an emphasis on its relative autonomy from class alignments (Anderson 1983). Nor did the various interpretations of the New Order in terms of 'bureaucratic authoritarianism' which cropped up in the 1980s as alternatives to structural-functionalism. None of those approaches helped to account for the extraordinary degree of personal ascendancy Soeharto was able to establish from about 1980 on, when he came to dominate the political scene completely for nearly two decades-primarily, I would argue, because of the increasingly patrimonialist character of the regime he created in those years. Without wanting to claim that Crouch had provided us with anything that can be compared with the grand theorising represented by the Almond and Coleman school or dependency theory, I think it can be said that he threw more light on the basic character of the Soeharto regime than any other analyst. 